\title{
Dopamine-Glutamate Interactions Controlling Prefrontal Cortical Pyramidal Cell Excitability Involve Multiple Signaling Mechanisms
}

\author{
Kuei Y. Tseng and Patricio O'Donnell \\ Center for Neuropharmacology and Neuroscience, Albany Medical College, Albany, New York 12208
}

\begin{abstract}
Although the importance of dopamine (DA) for prefrontal cortical (PFC) cognitive functions is widely recognized, the nature of DA actions in the PFC remains controversial. A critical component in DA actions is its modulation of glutamate transmission, which can be different when specific receptors are activated. To obtain a clear picture of cellular mechanisms involved in these interactions, we studied the effects of DA-glutamate coactivation on pyramidal cell excitability in brain slices obtained from developmentally mature rats using whole-cell patch-clamp recordings. Bath application of NMDA, AMPA, and the D1 agonist SKF38393 induced concentration-dependent excitability increases, whereas bath application of the D2 receptor agonist quinpirole induced a concentration-dependent excitability decrease. The NMDA-mediated response was potentiated by SKF38393. This NMDA-D1 synergism required postsynaptic intracellular $\mathrm{Ca}^{2+}$ and protein kinase A (PKA) and was independent of membrane depolarization. On the other hand, the excitatory effects of both NMDA and AMPA were attenuated by a D2 agonist. Surprisingly, the D2-NMDA interaction was also blocked by the $\mathrm{GABA}_{\mathrm{A}}$ antagonists bicuculline and picrotoxin, suggesting that the inhibitory action of D2 receptors on NMDA-induced responses in the PFC may be mediated by GABAergic interneurons. In contrast, the D2-AMPA interaction involves inhibition of PKA and activation of phospholipase lipase $\mathrm{C}-\mathrm{IP}_{3}$ and intracellular $\mathrm{Ca}^{2+}$ at a postsynaptic level. Thus, the modulatory actions of D1 and D2 receptors on PFC pyramidal cell excitability are mediated by multiple intracellular mechanisms and by activation of $\mathrm{GABA}_{\mathrm{A}}$ receptors, depending on the glutamate receptor subtypes involved.
\end{abstract}

Key words: prefrontal cortex; dopamine receptors; AMPA; NMDA; whole-cell patch clamp; electrophysiology

\section{Introduction}

The prefrontal cortex (PFC) receives widespread inputs from cortical and subcortical areas involved in sensorimotor and limbic functions. The integration of these glutamatergic inputs is essential for the PFC role in executive functions and goal-directed behavior (Miller, 2000). It is also well known that PFC activity is shaped by a number of neuromodulators, most notably monoamines. Among these, dopamine (DA) stands out as having an important role in PFC cognitive functions, including working memory, reward, and attention (Schultz, 2002). DA-containing neurons are located in the ventral tegmental area (Lindvall et al., 1974) and project to the PFC. Several studies have highlighted the need of DA-glutamate coactivation for a number of PFC functions (Gurden et al., 1999; Baldwin et al., 2002; Jay, 2003). Thus, the interactions between DA and glutamate receptors may be essential for a proper PFC function, and a thorough understanding of the cellular underpinnings of those interactions needs to be obtained.

\footnotetext{
Received Feb. 9, 2004; revised April 26, 2004; accepted April 26, 2004

This work was supported by National Institutes of Health Grant MH57683 and a National Alliance for Research on Schizophrenia and Depression Independent Investigator Award (P.0.).

Correspondence should be addressed to Kuei-Yuan Tseng, Center for Neuropharmacology and Neuroscience, Albany Medical College (MC-136), 47 New Scotland Avenue, Albany, NY 12208. E-mail: tsengky@mail.amc.edu. DOI:10.1523/JNEUROSCI.1021-04.2004

Copyright $\odot 2004$ Society for Neuroscience $\quad$ 0270-6474/04/245131-09\$15.00/0
}

DA affects glutamate function with different effects according to the receptors involved (Cepeda et al., 1993; Nicola et al., 2000), the cell type in which this interaction occurs (Nicola et al., 2000), and the membrane potential of the neuron (O'Donnell et al., 1999), as well as several other factors (Nicola et al., 2000; O'Donnell, 2003). In the striatum, for instance, D1 receptors potentiate responses mediated by NMDA receptors, whereas D2 receptors depress AMPA responses (Cepeda et al., 1993). A similar pattern has been reported in human neocortical neurons (Cepeda et al., 1992), and a D1 enhancement of NMDA responses has been observed in the PFC of young rats (Wang and O'Donnell, 2001). Despite the wealth of data indicating that DAglutamate interactions are essential for mature cognitive functions, the few studies conducted to address cellular mechanisms of these interactions have been performed in slices from prepubertal (typically $<40 \mathrm{~d}$ old) animals. Thus, the cellular mechanisms of DA-glutamate interactions that control pyramidal cell activity remain to be established in the mature PFC. This becomes essential because the effects observed in prepubertal animals may not necessarily reflect the function in adulthood. Neocortical pyramidal neurons undergo several morphological and physiological changes during postnatal development until postnatal day (P) 42 (Petit et al., 1988; Zhu, 2000). To confidently address DA-glutamate interactions as relevant to adult cognitive functions, we performed whole-cell patch-clamp recordings in 
brain slices obtained from developmentally mature (P42-65) rats. We examined the cellular mechanisms involved in the modulation of NMDA and AMPA responses by D1 and D2 receptors in medial PFC pyramidal neurons, measuring changes in cell excitability induced by combinations of DA and glutamate agonists and antagonists.

\section{Materials and Methods}

All experimental procedures were performed according to the United States Public Health Service Guide for Care and Use of Laboratory Animals and were approved by the Albany Medical College Institutional Animal Care and Use Committee. Male Sprague Dawley rats (Charles River Laboratories, Wilmington, MA) were maintained on a $12 \mathrm{hr}$ light/dark cycle with food and tap water available ad libitum until the time of the experiment. Rats were anesthetized with chloral hydrate $(400 \mathrm{mg} / \mathrm{kg}$, i.p.) before being decapitated. Brains were rapidly removed into ice-cold artificial CSF (ACSF) containing (in mM): $125 \mathrm{NaCl}, 25 \mathrm{NaHCO}_{3}, 10$ glucose, $3.5 \mathrm{KCl}, 1.25 \mathrm{NaH}_{2} \mathrm{PO}_{4}, 0.5 \mathrm{CaCl}_{2}, 3 \mathrm{MgCl}_{2}$, pH 7.45; osmolarity $295 \pm 5 \mathrm{mOsm}$. Coronal slices $(300 \mu \mathrm{m})$ containing the medial PFC were cut on a Vibratome in ice-cold ACSF, transferred, and incubated in warm $\left( \pm 35^{\circ} \mathrm{C}\right)$ ACSF solution constantly oxygenated with $95 \% \mathrm{O}_{2}-5 \% \mathrm{CO}_{2}$ for at least $90 \mathrm{~min}$ before recording.

Whole-cell patch-clamp recordings were performed in slices obtained from developmentally mature (P42-65) rats. Layers V-VI medial PFC pyramidal neurons were identified under visual guidance using infrareddifferential interference contrast (IR-DIC) video microscopy with a $40 \times$ water immersion objective. The image was detected with an IR-sensitive CCD camera and displayed on a monitor. All experiments were conducted at $33-35^{\circ} \mathrm{C}$. In the recording ACSF $(2 \mathrm{ml} / \mathrm{min}), \mathrm{CaCl}_{2}$ was increased to $2 \mathrm{~mm}$ and $\mathrm{MgCl}_{2}$ was decreased to $1 \mathrm{~mm}$. Patch pipettes (5-8 $\mathrm{M} \Omega$ ) were filled with (in $\mathrm{mM}$ ): $115 \mathrm{~K}$-gluconate, $10 \mathrm{HEPES}, 2 \mathrm{MgCl}_{2}, 20$ $\mathrm{KCl}, 2 \mathrm{MgATP}, 2 \mathrm{Na}_{2}$-ATP, $0.3 \mathrm{GTP}, \mathrm{pH}=7.3 ; 280 \pm 5 \mathrm{mOsm}$. All drugs were mixed into oxygenated ACSF and applied in the recording solution in known concentrations. Both control and drug-containing ACSF were oxygenated continuously throughout the experiments. SKF38393, quinpirole, eticlopride, and AMPA were purchased from Sigma (St. Louis, MO), and NMDA and SCH23390 were obtained from Research Biochemicals (Natick, MA). In some experiments, $10 \mu \mathrm{M}$ bicuculline (Sigma) or picrotoxin (Sigma) was applied in the bath to block $\mathrm{GABA}_{\mathrm{A}}$ receptors. For intracellular $\mathrm{Ca}^{2+}$ chelation, BAPTA (Sigma) was included in the recording micropipette at a concentration of $2 \mathrm{~mm}$. To block protein kinase A activity, $20 \mu \mathrm{M}$ peptide protein kinase inhibitor (PKI)-[5-24] (Calbiochem, La Jolla, CA) was included in the recording electrode, whereas $10 \mu \mathrm{M}$ U73122 and $2 \mu \mathrm{M}$ Xestospongin C (XeC) (Calbiochem) were used to block PLC and $\mathrm{IP}_{3}$, respectively.

Whole-cell current-clamp recordings were performed with a computer-controlled amplifier (MultiClamp 700A; Axon Instruments, Foster City, CA) and acquired with Axoscope 8.1 (Axon Instruments) at a sampling rate of $10 \mathrm{kHz}$. Electrode potentials were adjusted to zero before recording without correcting the liquid junction potential. In each cell, input resistance (measured by $200-300 \mathrm{msec}$ duration hyperpolarizing pulses), membrane potential, the number of evoked spikes, and the latency to the first spike evoked by a $500 \mathrm{msec}$ duration depolarizing current pulse were analyzed before and after drug treatment. Typically, baseline recordings were conducted for $\sim 10 \mathrm{~min}$ before perfusing with a solution containing the different mixture of drugs for 5-6 min. The effects of drug treatment were evident during the first 2-3 min and became stable during the remainder of the drug application. All neurons recorded in the present study showed a similar pattern of responses, and all data shown were analyzed from the stable 3-5 min period of drug administration. The effects observed with NMDA or AMPA required 5-10 min to wash out. In contrast, 15-20 min were required to partially wash out (they never reversed completely) the effects obtained with D1 and D2 agonists. Values of all measures are expressed as mean \pm SD. Drug effects were compared using repeated measures ANOVA, and the differences between experimental conditions were considered statistically significant when $p<0.05$.
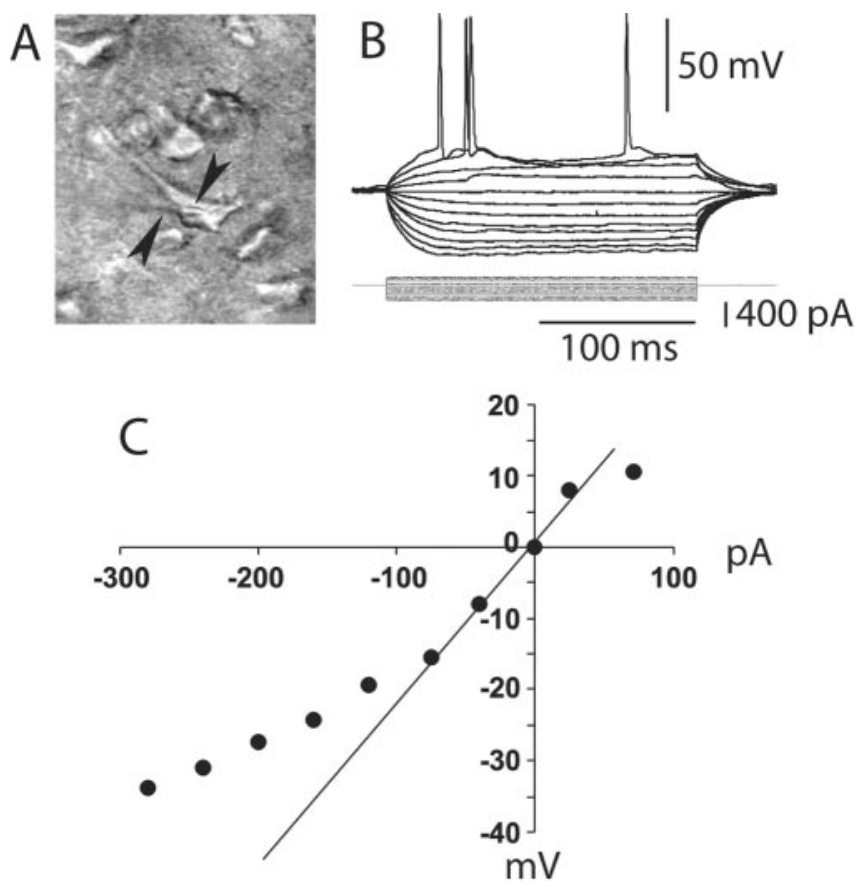

Figure 1. Whole-cell recording from PFC pyramidal neurons. A, IR-DIC image of a layer $V$ medial PFC pyramidal neuron recorded from a $300-\mu \mathrm{m}$-thick PFC slice (P52). The arrows point to the shadow of the recording electrode. $B$, Typical response to depolarizing and hyperpolarizing somatic current pulses ( $200 \mathrm{msec}$; from -300 to $+100 \mathrm{pA}$ ). C, Current-voltage plot from the traces shown in $B$. Currents larger than $-100 \mathrm{pA}$ yielded a marked inward rectification.

\section{Results}

Whole-cell current-clamp recordings of 242 pyramidal neurons located in deep layers of the medial PFC were conducted in brain slices obtained from young adult (P50.4 \pm 7.7 ; mean \pm SD) rats. Recordings were made using visual guidance under differential interface contrast in the infrared range, allowing selection of pyramidal neurons (Fig. 1A). All neurons recorded were silent at rest, and action potentials were observed only in response to depolarizing somatic current injection (Fig. $1 B$ ). The membrane potential of these neurons was $-69.8 \pm 3.2 \mathrm{mV}$, and their input resistance was $151.0 \pm 44.5 \mathrm{M} \Omega$ calculated from the linear portion of the $I-V$ curve in the hyperpolarized direction (Fig. 1C). Most pyramidal neurons recorded $(\sim 85 \%)$ exhibited an initial spike doublet followed by spike frequency accommodation in response to suprathreshold current steps (Fig. $1 B$ ) and typically showed inward rectification in response to a series of current pulses in both the hyperpolarizing and depolarizing directions (Fig. 1C). As measures of cell excitability, the number of spikes and the latency to the first spike evoked by the depolarizing current pulses were quantified. Changes in cell excitability induced by drugs (DA and glutamate agonists and antagonists) were assessed by repeated delivery of similar-intensity depolarizing pulses while the agents were added to the bath. In some experiments $(n=83$ cells), neurons were filled with Neurobiotin $(0.125 \%)$ to further confirm the cell type as well as the recording site. All cells filled with Neurobiotin were identified as pyramidal neurons located in layer V or VI of the medial PFC.

\section{D1 and D2 receptors have opposite effects on PFC pyramidal neuron excitability}

D1 and D2 agonists affected differentially the number of spikes and latency to the first spike evoked by constant-amplitude de- 

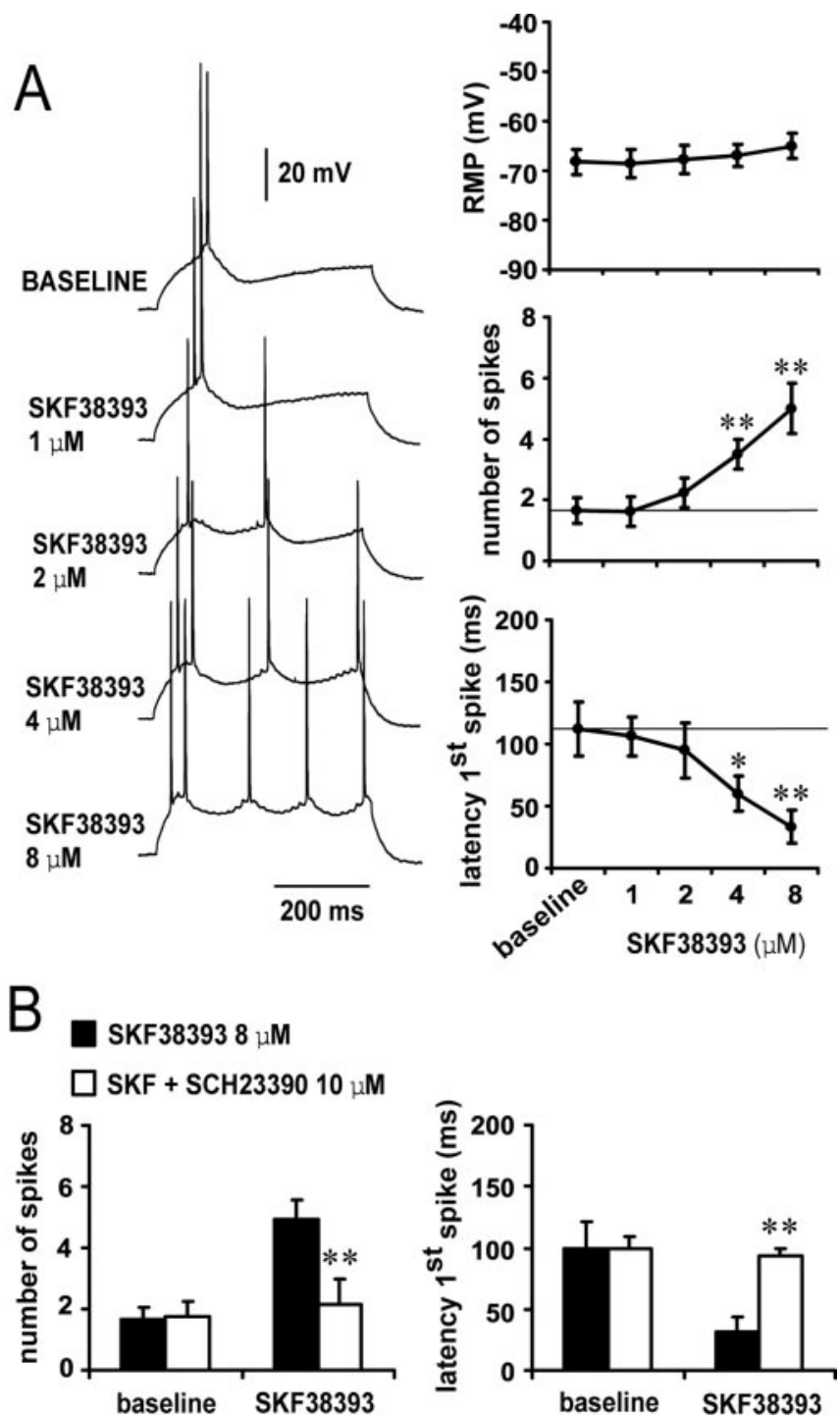

Figure 2. D1 activation enhances pyramidal cell excitability. $A$, Concentration-dependent excitability increases induced by bath application of SKF38393 in the PFC. Left panel, Representative tracings showing the increased action potential firing evoked by depolarizing current injection in the presence of 1, 2, 4, and $8 \mu \mathrm{m}$ SKF38393 concentrations. Right panel, Dosedependent effect of SKF38393 on pyramidal cell excitability (measured as the latency to the first evoked spike and the number of spikes evoked by depolarizing current injection). The resting membrane potential was not significantly affected by bath application of SKF38393; however, the number of spikes was increased significantly and the latency to the first spike decreased with 4 and $8 \mu \mathrm{M}$ SKF38393 (compared with baseline; ${ }^{*} p<0.005$, ${ }^{* *} p<0.0002$; repeated measures ANOVA). B, Bar graphs illustrating that the effects of $8 \mu \mathrm{m}$ SKF38393 on pyramidal cell excitability were blocked by the D1 antagonist $\mathrm{SCH} 23390(10 \mu \mathrm{M})$. The excitatory action of $8 \mu \mathrm{M}$ SKF38393 on both the number of evoked spikes (left) and first spike latency were prevented by SCH23390 (compared with SKF38393 alone; ${ }^{* *} p<0.005$; repeated measures ANOVA).

polarizing current pulses. Bath application of the D1 agonist SKF38393 resulted in a concentration-dependent excitability increase ( $n=5-10$ cells per dose). The number of spikes increased significantly from $1.7 \pm 0.4$ spikes (baseline) to $3.5 \pm 0.5$ spikes $(4 \mu \mathrm{M}$ SKF38393) and $5.0 \pm 0.8$ spikes $(8 \mu \mathrm{M}$ SKF38393) (Fig. $2 A)$. Similarly, the latency to the first evoked spike was reduced from $111.9 \pm 21.8 \mathrm{msec}$ (baseline) to $60.1 \pm 14.0$ and $33.3 \pm 13.5$ msec with 4 and $8 \mu \mathrm{M}$ SKF38393, respectively (Fig. 2A). This effect was independent of membrane potential changes and was blocked by the D1 antagonist SCH23390 (10 $\mu \mathrm{M} ; n=4)$ (Fig. $2 B)$. No significant changes were observed with SKF38393 on
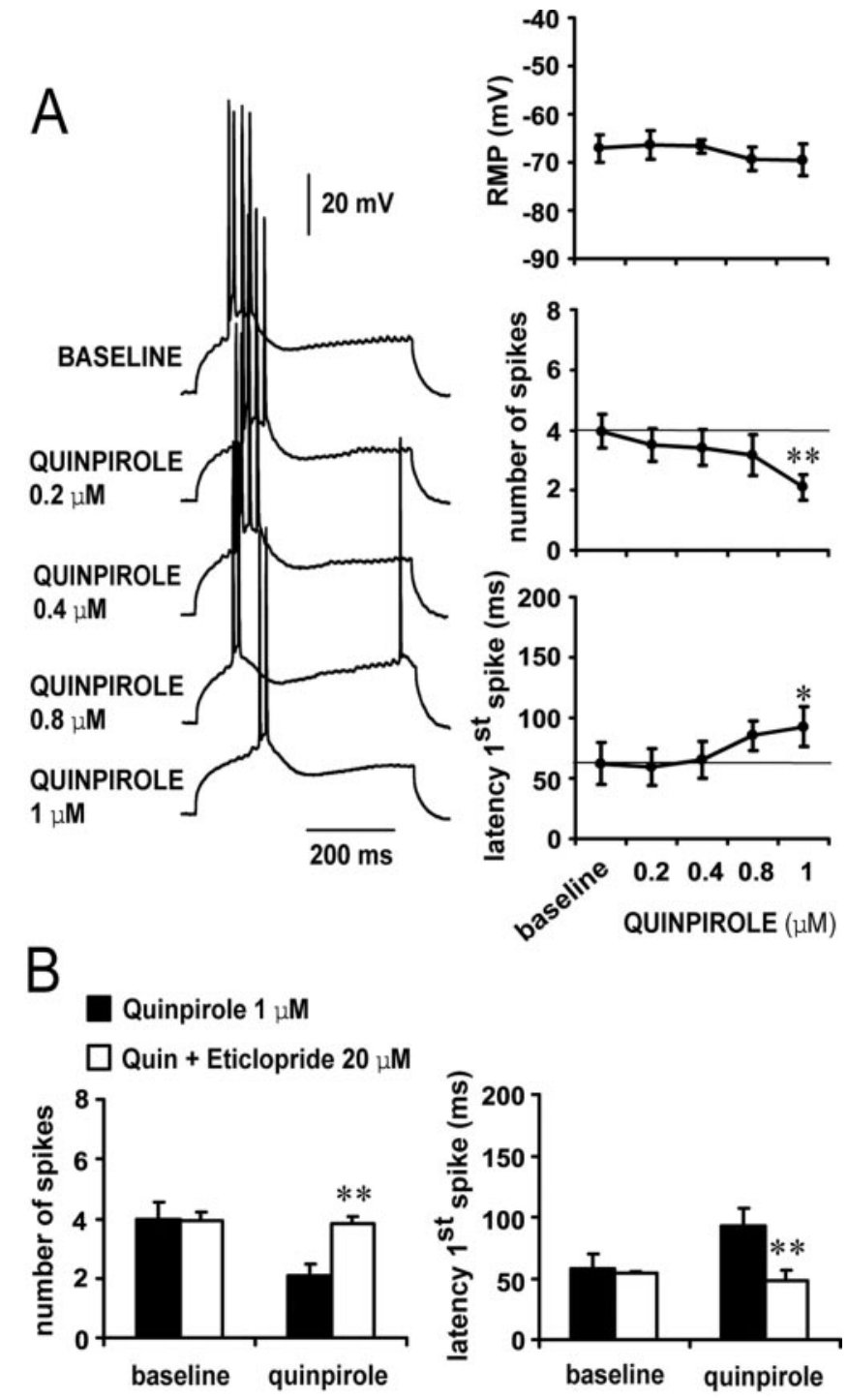

Figure 3. D2 receptors decrease pyramidal cell excitability. $A$, Concentration-dependent excitability decreases induced by bath application of quinpirole in the PFC. Left panel, Traces recorded from a single neuron illustrating the effects of increasing quinpirole concentrations on action potential firing evoked by depolarizing current injection. Right panel, Dose-dependent effect of quinpirole on PFC pyramidal cell excitability. A significant decrease in the number of evoked spikes and increased first spike latency were observed only with $1 \mu \mathrm{m}$ quinpirole (compared with baseline; ${ }^{* *} p<0.001,{ }^{*} p<0.01$; repeated measured ANOVA). No changes were observed in membrane potential. $B$, The inhibitory action of $1 \mu$ m quinpirole on PFC pyramidal cell excitability was blocked by $20 \mu \mathrm{m}$ eticlopride (compared with quinpirole alone; ${ }^{* *} p<$ 0.001 ; repeated measures ANOVA).

input resistance or action potential kinetics (spike threshold and duration; data not shown). On the other hand, bath application of the D2 agonist quinpirole induced a decrease in excitability without changes in membrane potential or action potential threshold or kinetics ( $n=5-6$ cells per dose). Input resistance increased from $140.6 \pm 38.2$ (baseline) to $162.7 \pm 36.4 \mathrm{M} \Omega$ in the presence of $1 \mu \mathrm{M}$ quinpirole ( $p<0.05$; paired $t$ test). The number of evoked spikes was significantly reduced from $4.0 \pm 0.6$ (baseline) to $2.1 \pm 0.4$ spikes, and the latency to the first evoked spike was increased from $62.1 \pm 17.2 \mathrm{msec}$ (baseline) to $92.6 \pm 16.5$ msec in presence of $1 \mu \mathrm{M}$ quinpirole (Fig. $3 A$ ). This effect was prevented by pre-exposing the slice to the $\mathrm{D} 2$ antagonist eticlopride $(20 \mu \mathrm{M} ; n=4)$ (Fig. $3 B$ ). These results indicate that phar- 
macological activation of D1 receptors increase, whereas D2 receptors decrease, PFC pyramidal cell excitability.

Opposite action of $\mathrm{D} 1$ and $\mathrm{D} 2$ receptors on NMDA enhancement of cell excitability

Bath application of NMDA resulted in a concentration-dependent excitability increase in PFC pyramidal neurons. Significant increases in the number of evoked spikes and decreases in the latency to the first evoked spike were observed with 2, 4, and $8 \mu \mathrm{M}$, but not $1 \mu \mathrm{M}$, NMDA $(n=7-8$ cells per dose). No changes in input resistance, action potential threshold, or duration were observed. The number of evoked spikes increased significantly from $1.7 \pm$ 0.5 (baseline) to $4.0 \pm 1.4,7.0 \pm 1.4$, and $10.2 \pm 1.1$ spikes, and the latency to the first evoked spike decreased from 106.0 \pm $26.2 \mathrm{msec}$ (baseline) to $55.1 \pm 16.8,22.1 \pm$ 12.8 , and $7.9 \pm 6.6 \mathrm{msec}$ with 2,4 , and 8 $\mu \mathrm{M}$ SKF38393, respectively (Fig. 4). Adding an ineffective dose of the D1 agonist (2 $\mu \mathrm{M}$ ) (Fig. $2 A$ ) potentiated the excitatory effects of NMDA on both number of spikes and latency to the first evoked spike ( $n=8-10$ cells per dose). A D1 enhancement of NMDA-mediated responses was observed for 1 and $2 \mu \mathrm{M}$ but not 4 and 8 $\mu \mathrm{M}$ NMDA (Fig. 4). In contrast, NMDAmediated excitability increase was attenuated by coadministration of the $\mathrm{D} 2$ agonist quinpirole $(0.4 \mu \mathrm{M} ; n=6-8$ cells per dose) (Fig. 4), which was ineffective when applied alone at this concentration (Fig. $3 A$ ). This inhibitory action of quinpirole was effective for 2,4 , and $8 \mu \mathrm{M}$ NMDA. These results indicate that D1 receptors facilitate and D2 receptors depress NMDAmediated responses in mature PFC pyramidal neurons.

\section{D2 receptors attenuate the AMPA-} mediated excitability increase in PFC pyramidal neurons

Bath application of AMPA also induced concentration-dependent increases in PFC pyramidal cell excitability. The number of spikes significantly increased from $1.8 \pm 0.4$ (baseline) to $5.5 \pm 1.5,7.5 \pm 0.8$, and $10.1 \pm 1.4$ spikes $(n=6-7$ per dose) with $0.1,0.2$, and $0.4 \mu \mathrm{M}$ AMPA, respectively (Fig. 5). No changes in input resistance were detected. These effects were accompanied by significant decreases in the first spike latency from $94.2 \pm 36.6 \mathrm{msec}$ to $23.7 \pm 10.2,18.4 \pm 9.0$, and $8.0 \pm 4.5$ msec, respectively (Fig. 5). This excitatory action of AMPA was not affected by $2 \mu \mathrm{M}$ SKF38393. The D1 agonist failed to modify any electrophysiological effect of AMPA (Fig. 5) $(n=5-6$ cells per dose). In contrast, the increases in cell excitability brought by
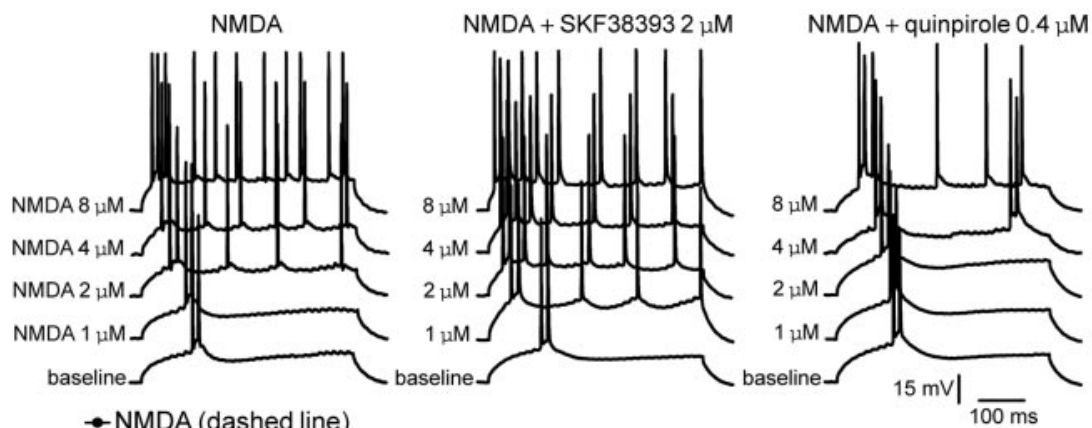

$\rightarrow$ NMDA (dashed line)

-NMDA + SKF383932 $\mu \mathrm{M}$
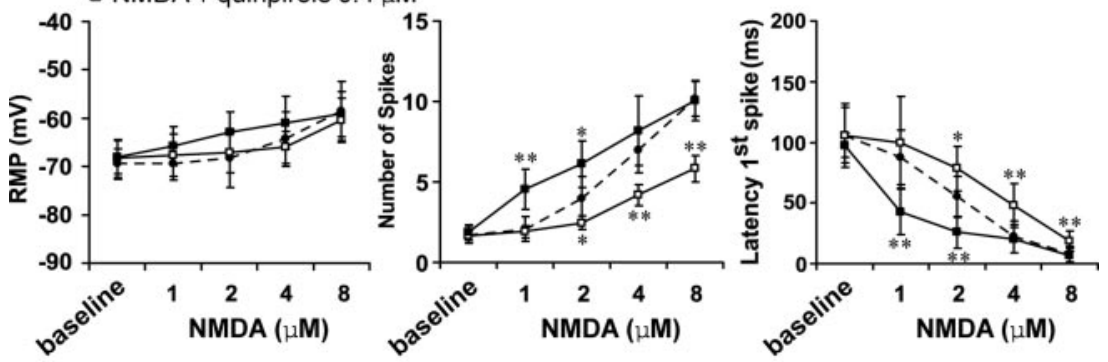

Figure 4. D1 and D2 modulation of NMDA effects on PFC cell excitability. Top, Overlay of tracings obtained with increasing NMDA concentrations (bottom to top) illustrating the effect of NMDA alone (left), NMDA plus SKF38393 (center), and NMDA plus quinpirole (right). Bottom, Graphs summarizing the effects of increasing NMDA concentrations on PFC pyramidal cell resting membrane potential (left), number of evoked spikes (center), and first spike latency (right). SKF38393 (2 $\mu \mathrm{M})$ significantly enhanced the effects of 1 and $2 \mu \mathrm{m}$ NMDA. In contrast, the effect of NMDA was significantly reduced in presence of quinpirole $(0.4$ $\mu \mathrm{M}) .{ }^{*} p<0.03 ;{ }^{* *} p<0.002 ;$ Tukey post hoc test after significant ANOVA.
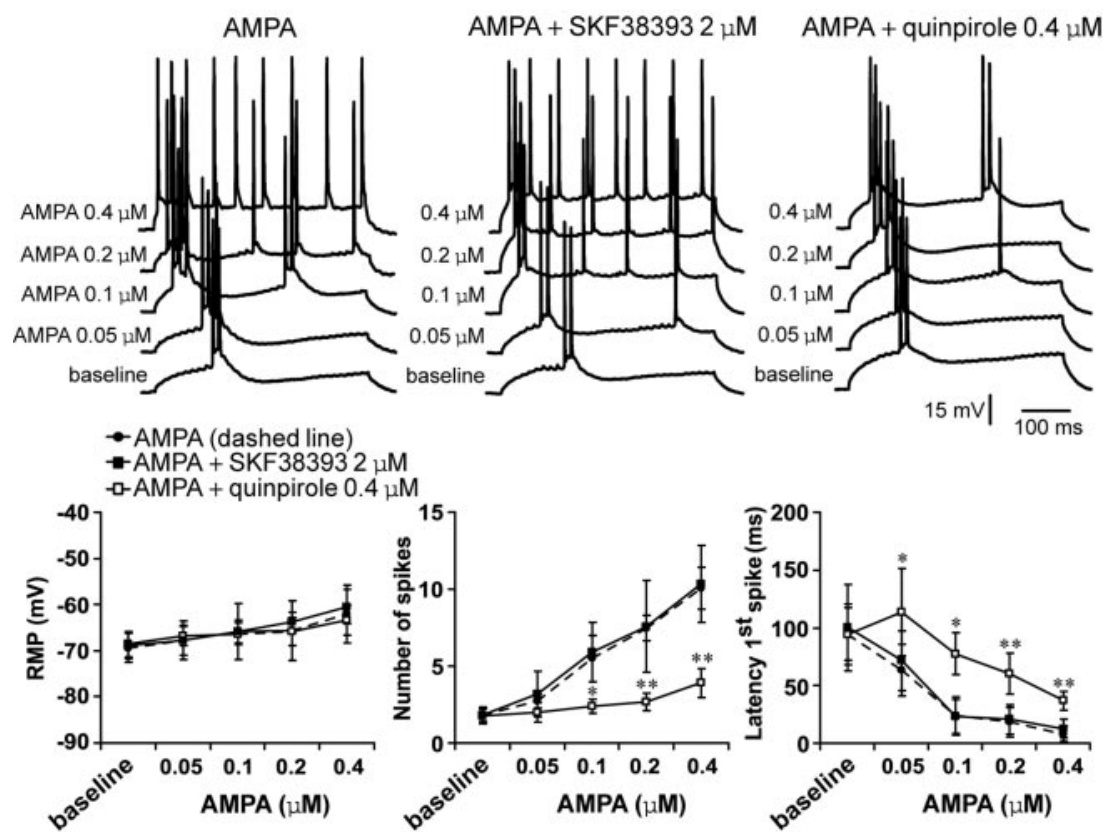

Figure 5. D1 and D2 modulation of AMPA effects on PFC pyramidal cell excitability. Top, Overlays of traces obtained with increasing AMPA concentrations (bottom to top) illustrating the effects of AMPA alone (left), AMPA plus SKF38393 (center), and AMPA plus quinpirole (right). Bottom, Plots summarizing the effects of increasing AMPA concentrations (alone and in the presence of either a D1 or a D2 agonist) on PFC pyramidal cell resting membrane potential, number of evoked spikes, and latency to the first evoked spike. The excitatory effect of AMPA was attenuated in the presence of $0.4 \mu \mathrm{m}$ quinpirole. SKF38393 failed to change any AMPA-mediated electrophysiological action. ${ }^{*} p<0.03 ;{ }^{* *} p<0.001$; Tukey post hoc test after significant ANOVA.

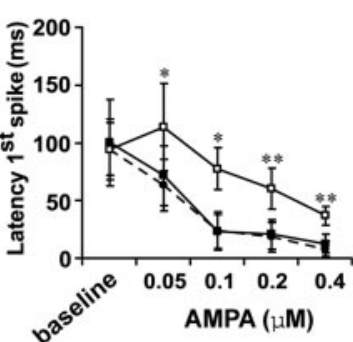

$0.1,0.2$, and $0.4 \mu \mathrm{M}$ AMPA were significantly attenuated by 0.4 $\mu \mathrm{M}$ quinpirole (Fig. 5) ( $n=7-9$ cells per dose), which was ineffective when applied alone (Fig. 3A). Input resistance and spike kinetics remained unchanged across doses (data not shown). 

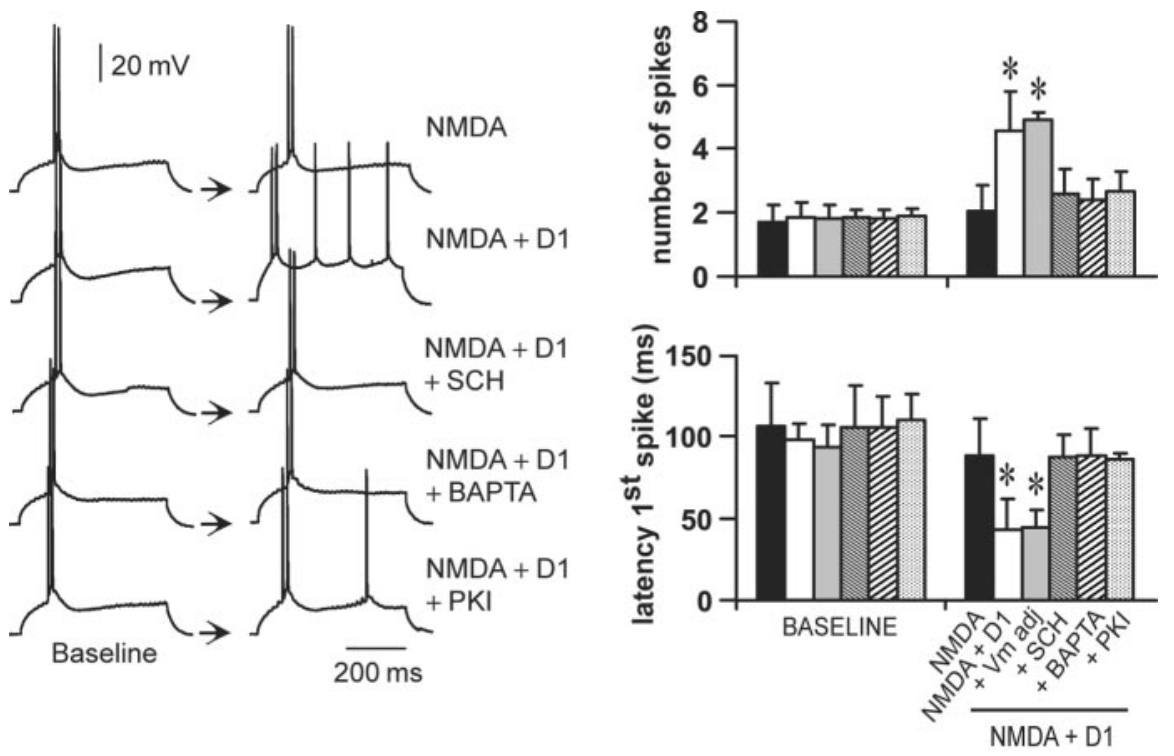

Figure 6. The D1 enhancement of NMDA response is independent of membrane depolarization and requires intracellular $\mathrm{Ca}^{2+}$ and PKA activation. Left, Representative traces illustrating the response of a PFC pyramidal neuron to intracellular current injection after (from top to bottom) NMDA (1 $\mu \mathrm{m}$ ), NMDA plus SKF38393 (2 $\mu \mathrm{M})$, NMDA plus SKF38393 plus SCH23390 (10 $\mu \mathrm{m}$ ), NMDA plus SKF38393 plus the $\mathrm{Ca}^{2+}$ chelator BAPTA (2 mm), and NMDA plus SKF38393 plus the PKA blocker PKI-[5-24] (20 $\left.\mu \mathrm{m}\right)$. Right, Bar graphs summarizing the changes in number of evoked spikes and first spike latency observed in each experimental condition. The synergistic D1-NMDA effect on the number of evoked spikes and first spike latency was not affected by holding the resting membrane potential at baseline value (Vm adj). This potentiation was blocked by $\mathrm{SCH} 23390(10 \mu \mathrm{m})$ and in recordings with electrodes containing BAPTA (2 mm) or PKI-[5-24] (20 $\mu \mathrm{M}) .{ }^{*} p<0.001$; Tukey post hoc test after significant ANOVA.
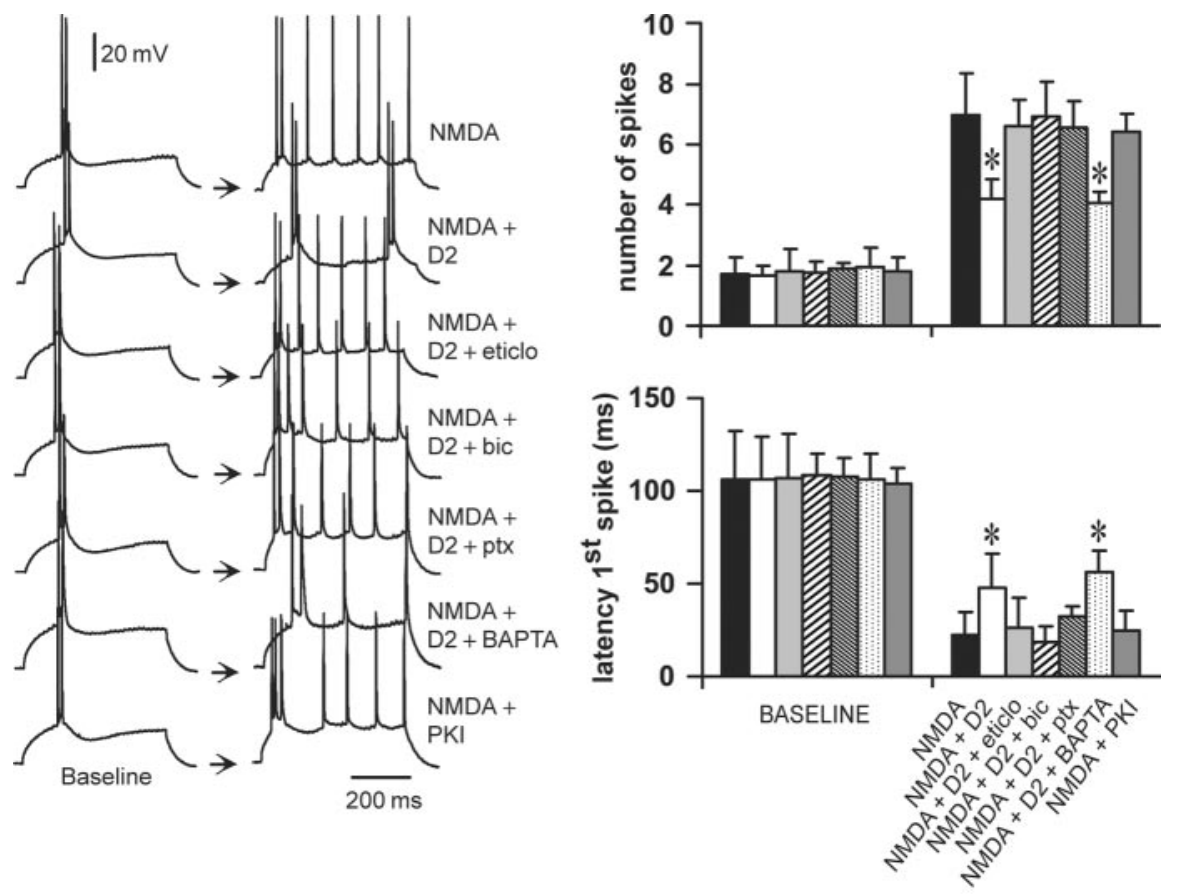

Figure 7. D2-NMDA interactions involve $G_{A B A}$ receptors. Left, Traces of responses to current injection illustrating changes in action potential firing observed in the different experimental conditions. From top to bottom, the traces are representative recordings obtained with NMDA alone $(4 \mu \mathrm{m})$, NMDA plus quinpirole $(0.4 \mu \mathrm{m})$, NMDA plus quinpirole plus the D2 antagonist eticlopride (20 $\mu \mathrm{m}$; eticlo), NMDA plus quinpirole plus the $\mathrm{GABA}_{\mathrm{A}}$ antagonist bicuculline (10 $\mu \mathrm{m}$; bic), NMDA plus quinpirole plus the $\mathrm{GABA}_{\mathrm{A}}$ antagonist picrotoxin (10 $\mu \mathrm{m} ; \mathrm{ptx}$ ), NMDA plus quinpirole plus BAPTA-containing electrode (2 mM), and NMDA plus PKI [5-24]-containing electrode (20 mM). Right, Bars graphs summarizing the changes in number of evoked spikes and first spike latency in each experimental condition. The inhibitory effect of quinpirole on NMDA responses was blocked by eticlopride ( $20 \mu \mathrm{m} ;$ $n=5)$, by bicuculline $(10 \mu \mathrm{m} ; n=6)$, and by picrotoxin $(10 \mu \mathrm{m} ; n=6)$ but not in recordings with electrodes containing the calcium chelator BAPTA $(n=6)$. Intracellular application of the PKA inhibitor PKI-[5-24] $(n=5)$ failed to mimic the effects of quinpirole. ${ }^{*} p<0.001$; Tukey post hoc test after significant ANOVA.
These results indicate that AMPA effects on PFC pyramidal cell excitability are not affected by D1 but are strongly inhibited by $\mathrm{D} 2$ receptors.

\section{The D1-NMDA synergism is} independent of membrane depolarization and requires both intracellular $\mathrm{Ca}^{2+}$ and protein kinase $\mathrm{A}$ activation

The D1 enhancement of NMDA responses can be prevented by administration of a D1 antagonist. As shown above, coadministration of SKF38393 $(2 \mu \mathrm{M})$ and NMDA $(1 \mu \mathrm{M})(n=8)$ significantly increased the number of spikes and decreased the latency to the first evoked spike when compared with NMDA alone $(n=8)$ (Fig. 6). This potentiation was blocked by the D1 antagonist SCH23390 (10 $\mu \mathrm{M} ; n=7)$ (Fig. 6) and by the NMDA blocker APV ( $50 \mu \mathrm{M}$; $n=5$; data not shown), confirming that it results from D1-NMDA interactions. To account for any role of the slight depolarization elicited by this combination of drugs $(\sim 3.5 \mathrm{mV})$, cell excitability was determined in some cases $(n=6)$ after adjusting the membrane potential to baseline value with intracellular current injection. The D1 agonist was still able to potentiate NMDA effects, suggesting that the D1-NMDA synergism on PFC pyramidal cell excitability is independent of membrane depolarization (Fig. 6).

It has been shown that D1-NMDA interactions involve intracellular $\mathrm{Ca}^{2+}$ and protein kinase A (PKA) (Cepeda and Levine, 1998; Cepeda et al., 1998; Wang and O'Donnell, 2001). To determine whether this is also the case in slices from mature animals, a subset of recordings was conducted with electrodes containing the $\mathrm{Ca}^{2+}$ chelator BAPTA ( $\left.2 \mathrm{mM} ; n=5\right)$ or the PKA inhibitor peptide PKI-[5-24] (20 $\mu \mathrm{M} ; n=5)$. In those experiments, the D1 agonist failed to potentiate NMDA effects (Fig. 6). No apparent changes in input resistance or action potential threshold were observed. These results indicate that D1NMDA interactions on PFC pyramidal cell excitability require intracellular $\mathrm{Ca}^{2+}$ and activation of a PKA cascade at a postsynaptic level.

\section{D2-NMDA interactions require} activation of $\mathrm{GABA}_{\mathrm{A}}$ receptors

To study the cellular mechanisms involved in D2-NMDA interactions, a low dose of the D2 agonist quinpirole $(0.4 \mu \mathrm{M})$ (Fig. 3) was combined with $4 \mu \mathrm{M}$ NMDA (Fig. 4), and different intracellular cascades were blocked with selective antagonists. Although bath application of $0.4 \mu \mathrm{M}$ 

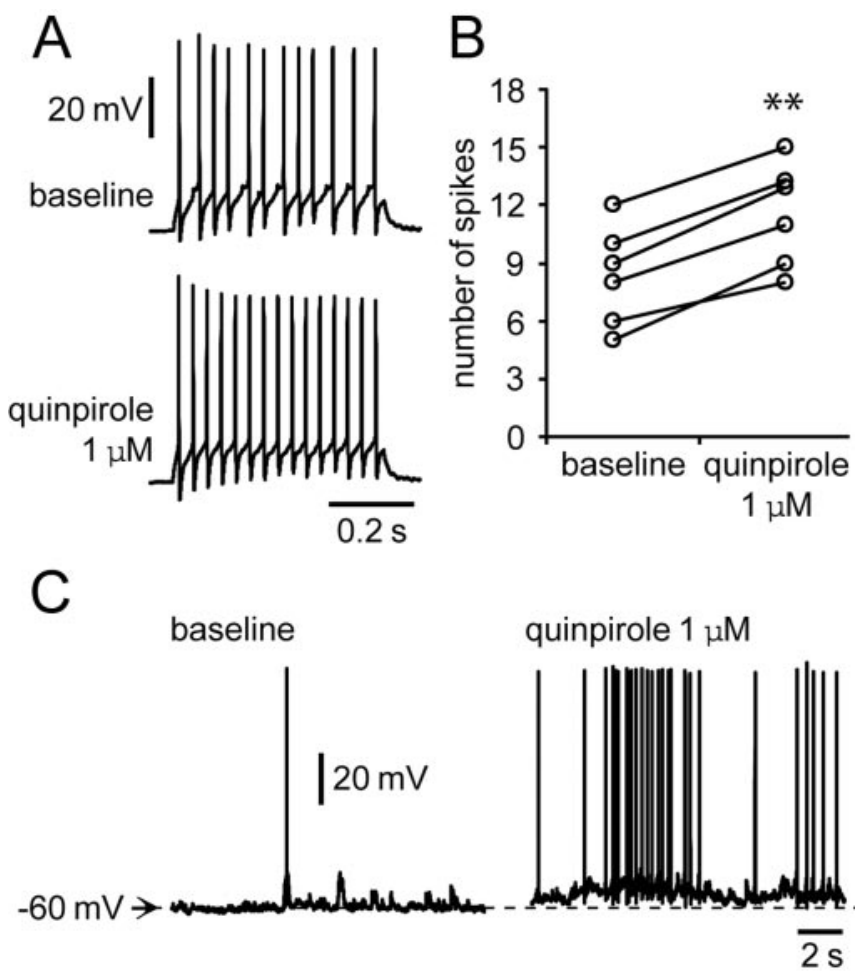

Figure 8. Quinpirole enhances interneuron excitability. A, Representative traces of responses to current injection showing the effect of quinpirole $(1 \mu \mathrm{M})$ on interneuron excitability. The number of evoked spikes increased from 12 to 15 . B, Scatter graph summarizing the excitatory effect of quinpirole on PFC interneurons. The number of spikes evoked by intracellular current injection increased significantly in the presence of quinpirole $1 \mu \mathrm{m}\left(n=6\right.$; ${ }^{* *} p<$ 0.001 ; paired $t$ test). C, A pair of traces illustrating the membrane depolarization with increased firing rate induced by quinpirole.

quinpirole failed to modify pyramidal cell excitability when applied alone (Fig. 3), it significantly reduced the excitability increase induced by $4 \mu \mathrm{M}$ NMDA (Fig. 7$)(n=7)$. This interaction was blocked by the D2 antagonist eticlopride ( $20 \mu \mathrm{M} ; n=5)$ (Fig. 7), confirming that it is a D2-mediated effect. Surprisingly, the interaction was also blocked by the $\mathrm{GABA}_{\mathrm{A}}$ antagonist bicuculline $(10 \mu \mathrm{M} ; n=6)$ or picrotoxin $(10 \mu \mathrm{M} ; n=6)$ (Fig. 7) without significant changes in cellular input resistance and action potential kinetics. Recordings with electrodes containing the $\mathrm{Ca}^{2+}$ chelator BAPTA ( $2 \mathrm{~mm} ; n=6$ ) failed to prevent the inhibitory action of quinpirole on NMDA responses.

It is well known that D2 receptors inhibit adenylyl cyclase, reducing cytosolic cAMP levels and PKA activity (Lachowicz and Sibley, 1997). Therefore, a subset of experiments was conducted to investigate the role of PKA by including the PKA inhibitor PKI-[5-24] $(20 \mu \mathrm{M} ; n=5)$ in the recording electrodes instead of bath application of quinpirole. Intracellular application of the PKA inhibitor peptide PKI-[5-24] was unable to mimic the effects of quinpirole on NMDA-mediated excitability increase (Fig. 7). These results suggest that the inhibitory effect of D2 receptors on NMDA-mediated responses in PFC pyramidal neurons requires $\mathrm{GABA}_{\mathrm{A}}$ receptor activation but does not involve postsynaptic intracellular $\mathrm{Ca}^{2+}$ or blockade of a PKA cascade via activation of the G-protein $\mathrm{G}_{\mathrm{i}}$.

It is therefore possible that the inhibitory D2 action on NMDA responses is mediated by activation of GABAergic interneurons. To test this hypothesis, recordings were conducted in interneurons to investigate the impact of the D2 agonist on their activity. To minimize the impact of interneuron diversity, we selected only interneurons located in layers III-V that had a fast spiking response to current pulse injection. Bath application of $1 \mu \mathrm{M}$ quinpirole enhanced PFC interneuron excitability. The number of spikes evoked by somatic current injection increased significantly from $8.3 \pm 2.6$ (baseline) to $11.5 \pm 2.7$ with quinpirole $(n=6$; $p<0.001$; paired $t$ test) (Fig. $8 A, B$ ). Input resistance increased from $282.0 \pm 18.4$ to $340.8 \pm 28.4 \mathrm{M} \Omega(p<0.001$; paired $t$ test), and the neurons were depolarized from $-63.2 \pm$ 1.4 to $-59.9 \pm 2.7 \mathrm{mV}(p=0.029$; paired $t$ test $)$. In those cells showing spontaneous action potential firing $(n=3)$, the depolarization was accompanied by an increase in firing rate (Fig. $8 C$ ). These results reinforce the notion that D2-NMDA interactions in the PFC may involve activation of GABAergic interneurons.

\section{D2-AMPA interactions require activation of a postsynaptic} PLC- $-\mathrm{IP}_{3}-\mathrm{Ca}^{2+}$ cascade

Bath application of $0.2 \mu \mathrm{M}$ AMPA and $0.4 \mu \mathrm{M}$ quinpirole was used to examine the cellular mechanisms involved in D2-AMPA interactions. The excitatory effects of $0.2 \mu \mathrm{M}$ AMPA on both the number of evoked spikes and the latency to the first spike were significantly attenuated by $0.4 \mu \mathrm{M}$ quinpirole (Fig. 9) $(n=9)$. These inhibitory actions of quinpirole on AMPA responses were blocked by the $\mathrm{D} 2$ receptor antagonist eticlopride $(20 \mu \mathrm{M} ; n=5)$ but not by the $\mathrm{GABA}_{\mathrm{A}}$ antagonist bicuculline $(10 \mu \mathrm{M} ; n=6)$ (Fig. 9). In contrast to the modulation of NMDA responses by D2 receptors, a D2-AMPA interaction could not be observed in recordings with electrodes containing the $\mathrm{Ca}^{2+}$ chelator BAPTA $(2$ $\mathrm{mM} ; n=6$ ) (Fig. 9). This suggests that the D2 reduction of AMPA responses occurs at a postsynaptic level and requires intracellular $\mathrm{Ca}^{2+}$. Intracellular administration of $20 \mu \mathrm{M}$ PKI-[5-24] significantly reduced the excitatory effects of $0.2 \mu \mathrm{M}$ AMPA $(n=6)$ but fell short of completely mimicking the effects of quinpirole (Fig. 9). This suggests that blockade of PKA pathways may be a mechanism by which D2 receptors downregulate AMPA activity, but it also indicates that another intracellular pathway may be involved in this interaction.

Given that D2-AMPA interactions require intracellular $\mathrm{Ca}^{2+}$, it is possible that the inhibitory action of $\mathrm{D} 2$ receptors on AMPA responses also involves activation of the $\mathrm{PLC}-\mathrm{IP}_{3}$ pathway (Sternweis and Smrcka, 1992; Hernandez-Lopez et al., 2000; Kotecha et al., 2002). To test this hypothesis, the effects of the PLC blocker U73122 (Kotecha et al., 2002) and the $\mathrm{IP}_{3}$ inhibitor XeC (Kotecha et al., 2002) were examined in the presence of $0.4 \mu \mathrm{M}$ quinpirole and $0.2 \mu \mathrm{M}$ AMPA. Intracellular application of $10 \mu \mathrm{M}$ $\mathrm{U} 73122(n=5)$ or $2 \mu \mathrm{M} \mathrm{XeC}(n=5)$ prevented the inhibitory effect of quinpirole on AMPA-mediated excitability increase (Fig. 9), without apparent changes in input resistance or action potential threshold and duration. Together, these results indicate that D2-AMPA interactions in the PFC involve several mechanisms, including intracellular $\mathrm{Ca}^{2+}$, activation of a PLC- $\mathrm{IP}_{3}$ pathway, and inhibition of PKA at a postsynaptic level.

\section{Discussion}

The modulatory actions of D1 and D2 receptors on NMDA and AMPA responses of PFC pyramidal neurons were studied in brain slices obtained from developmentally mature rats. Because recordings were not voltage clamped, the interactions examined here may reflect the natural behavior of the neurons.

D1 receptors enhance NMDA responses via PKA activation. It is well known that D1 agonists increase cAMP levels and PKA activity (Surmeier et al., 1995; Nicola et al., 2000), activating the phosphoprotein DARPP-32 (dopamine receptor-activated phospho protein $32 \mathrm{kDa}$ (Snyder et al., 1998), which can enhance 

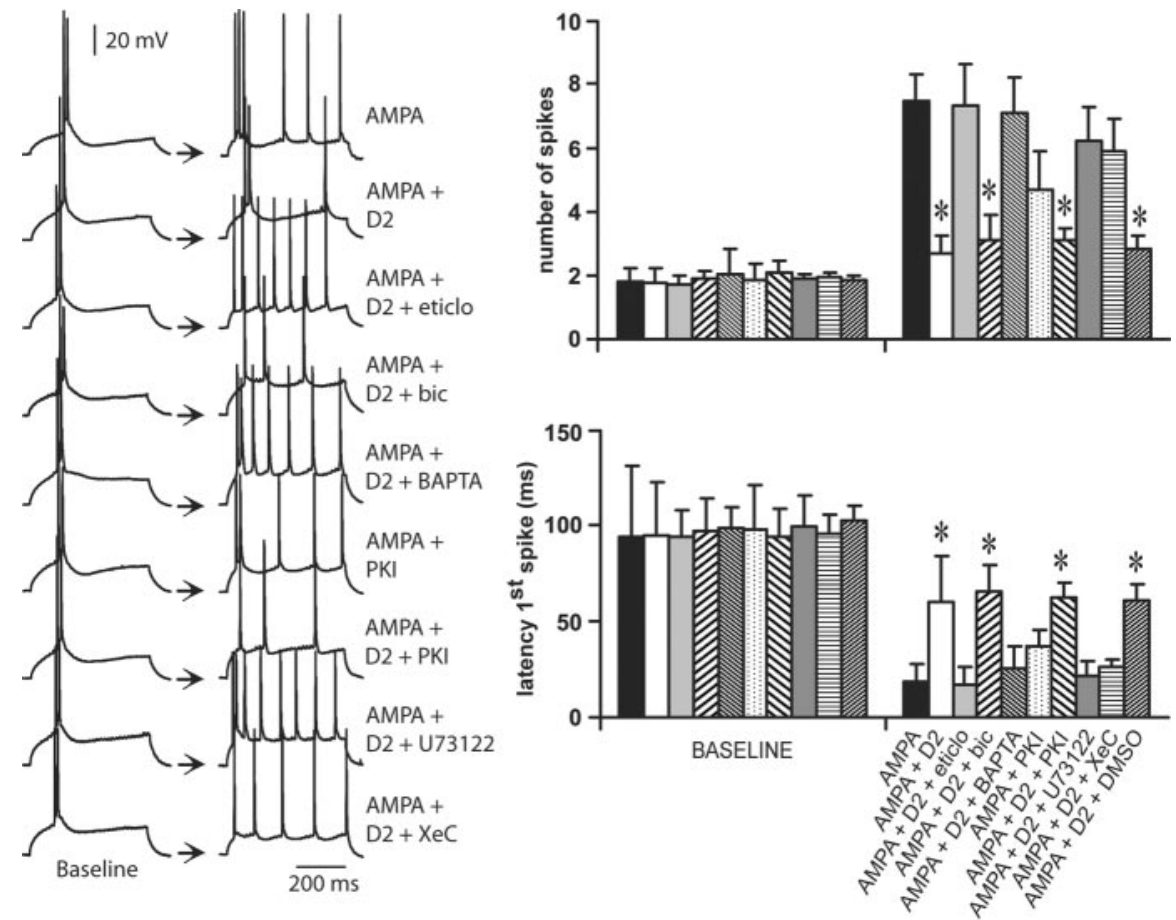

Figure 9. D2-AMPA interactions require intracellular $\mathrm{Ca}^{2+}, \mathrm{PLC}-\mathrm{IP}_{3}$ pathway, and PKA inactivation. Left panel, Traces of responses to current injection showing the effects of AMPA on PFC pyramidal cell action potential firing obtained in different experimental conditions. The pairs of traces (baseline and treatment) are representative of (from top to bottom) experiments conducted with AMPA $(0.2 \mu \mathrm{M})$, AMPA plus quinpirole $(0.4 \mu \mathrm{m})$, AMPA plus quinpirole plus eticlopride (20 $\mu \mathrm{m}$; eticlo), AMPA plus quinpirole plus bicuculline (10 $\mu \mathrm{m}$; bic), AMPA plus quinpirole plus BAPTA (2 mM), AMPA plus PKI-[5-24] (20 $\mu \mathrm{m})$, AMPA plus quinpirole plus PKI-[5-24] (20 $\mu \mathrm{M})$, AMPA plus quinpirole plus the PLC blocker U73122 (10 $\mu \mathrm{M})$, and AMPA plus quinpirole plus the $\mathbb{I P}_{3}$ inhibitor Xec $(2 \mu \mathrm{M})$. Right, Bar graphs summarizing the changes in number of evoked spikes and first spike latency observed in each experimental condition. The effect of quinpirole on AMPA responses was blocked by eticlopride but not bicuculline. In the presence of PKI-[5-24], the excitatory effect of AMPA on PFC pyramidal cell excitability was partially attenuated. Recordings with electrodes containing BAPTA, U-73122, or Xestospongin-C were able to block the inhibitory action of D2 receptors on AMPA-mediated effects. Intracellular application of $0.15 \%$ DMSO did not alter the effects of quinpirole on AMPA responses $(n=5) .{ }^{*} p<0.001$; Tukey post hoc test after significant ANOVA.

NMDA currents in striatal medium spiny neurons (FloresHernandez et al., 2002). We have reported previously a PKAdependent D1 potentiation of NMDA effects in PFC slices from young (P24-28) animals (Wang and O'Donnell, 2001). This signaling cascade could phosphorylate a number of proteins involved in NMDA responses, including the NMDA receptors themselves (Snyder et al., 1998). Other cellular mechanisms that could be involved in a D1 potentiation of NMDA responses include NMDA receptor trafficking to the postsynaptic membrane, as observed in striatal neurons (Dunah and Standaert, 2001), or actions on voltage-gated ion channels. A D1 modulation of NMDA receptor trafficking in PFC pyramidal neurons remains to be determined. Thus, the ability of D1 receptors to enhance NMDA-mediated excitability via PKA signaling could take place via different factors, including glutamate receptors or voltagegated ion channels activated downstream of NMDA receptors.

The modulatory D1 action on AMPA responses is complex, with evidence supporting both positive and negative interactions. In the striatum, D1 receptors increased AMPA-evoked cell firing (Cepeda et al., 1993) but produced little net change on synaptic responses (Levine et al., 1996). A D1 enhancement of AMPA responses has been reported in layer II-III PFC pyramidal neurons (Gonzalez-Islas and Hablitz, 2003). In layer V, however, D1 receptors can attenuate AMPA synaptic responses (Gao et al., 2001). Here we failed to find consistent D1 modulation of AMPA effects. Because cell excitability measured in response to somatic current injection reflects essentially postsynaptic effects, a presynaptic D1 action (Gao et al., 2001) would certainly be missed. At a postsynaptic level, however, there appears not to be a D1-AMPA interaction.

D2 receptors can modulate neuronal activity in many cortical and subcortical brain regions. For example, D2 receptors depress glutamate responses in striatal (Cepeda et al., 1993; O’Donnell and Grace, 1994) and hippocampal (Kotecha et al., 2002) neurons. A similar D2 inhibitory action on PFC pyramidal cell excitability has been observed in immature animals (Gulledge and Jaffe, 1998). The cellular mechanisms yielding D2 inhibitory actions may include multiple intracellular cascades (Cepeda et al., 1998; HernandezLopez et al., 2000; Kotecha et al., 2002) (for review, see Nicola et al., 2000). For instance, D2 receptors inhibit adenylyl cyclase via $G_{i}$, thereby reducing cellular levels of cAMP and PKA activity (for review, see Lachowicz and Sibley, 1997). Also, D2 receptors can modulate neuronal excitability by activating the $\mathrm{PLC}-\mathrm{IP}_{3}-\mathrm{Ca}^{2+}$ cascade (Hernandez-Lopez et al., 2000). Here we showed that a D2 attenuation of NMDA effects does not require intracellular $\mathrm{Ca}^{2+}$ or PKA inhibition. This interaction, however, was blocked by bicuculline or picrotoxin, suggesting that the D2 inhibitory effect on NMDA responses requires $\mathrm{GABA}_{\mathrm{A}}$ receptors. We also observed a D2mediated increase in firing rate and excitability of fast-spiking PFC interneurons. These findings are consistent with reports of the inhibitory effect of DA on PFC pyramidal cell firing being mediated, in part, by an increase in GABAergic transmission (Gulledge and Jaffe, 1998, 2001). Moreover, in vivo microdialysis from mature animals revealed a dose-dependent increase in extracellular GABA by intraPFC quinpirole, an effect blocked by D2 but not D1 antagonists (Grobin and Deutch, 1998). Thus, it is possible that D2 receptors attenuate PFC NMDA responses by exciting GABA interneurons.

An intriguing observation is that this D2-dependent GABA activation affects NMDA but not AMPA responses. Although speculative, a few potential explanations can be advanced. First, interneurons could be selectively activated by NMDA. This is unlikely because spontaneous and evoked IPSCs in pyramidal neurons are blocked by AMPA and not NMDA antagonists (Salin and Prince, 1996a; Ling and Benardo, 1999). Another possibility is that D2-activated interneurons release GABA acting on receptors located on NMDA-rich areas of the pyramidal cell membrane, enabling a GABA shunting effect only when NMDA receptors are activated. A spatial selectivity of NMDA and AMPA receptors in pyramidal neurons has been suggested, with NMDA preferentially located in the soma and proximal dendrites and AMPA in distal dendrites (Dodt et al., 1998). It has also been observed that GABA IPSCs are stronger in the soma (Salin and Prince, 1996b) compared with distal regions of pyramidal neurons. This would allow a stronger impact on membrane regions that express primarily NMDA receptors. Further experiments are 
necessary to elucidate how D2-GABA interactions control NMDA responses.

In contrast, the $\mathrm{D} 2$ inhibitory action on AMPA responses does not involve $\mathrm{GABA}_{\mathrm{A}}$ receptors. D2 effects on AMPA responses were blocked by intracellular BAPTA and by PLC and $\mathrm{IP}_{3}$ antagonists, suggesting that the interactions require intracellular $\mathrm{Ca}^{2+}$ and the PLC- $\mathrm{IP}_{3}$ cascade. Because this pathway is one of the primary mechanisms for receptor-mediated mobilization of intracellular $\mathrm{Ca}^{2+}$ (Sternweis and Smrcka, 1992), D2 receptors could promote intracellular $\mathrm{Ca}^{2+}$ release, enhancing $\mathrm{Ca}^{2+}$ dependent AMPA inactivation (Kotecha et al., 2002). Alternatively, D2 receptors could reduce L-type $\mathrm{Ca}^{2+}$ currents via the $\mathrm{PLC}-\mathrm{IP}_{3}$-calcineurin signaling pathway, thereby decreasing cell excitability (Hernandez-Lopez et al., 1997, 2000). In addition to the PLC- $-\mathrm{IP}_{3}-\mathrm{Ca}^{2+}$ cascade, we also observed that intracellular administration of a PKA blocker was able to reduce the excitability increase induced by AMPA. This suggests that the D2 inhibitory effect can be mimicked, albeit partially, by inactivation of the cAMP-PKA cascade. Thus, D2 receptors attenuate AMPAmediated responses in PFC pyramidal neurons through at least two different postsynaptic mechanisms.

A DA modulation of glutamate activity may be important for PFC function (Jay, 2003; O’Donnell, 2003). For instance, an intact mesocortical projection is necessary for hippocampal $\rightarrow$ PFC long-term potentiation (LTP) (Gurden et al., 1999), which is enhanced by D1 agonists (Gurden et al., 2000). Similarly, PFC D1 receptors improve memory retrieval (Floresco and Phillips, 2001), and coincident D1-NMDA activation in the PFC is required for appetitive instrumental learning (Baldwin et al., 2002). Because the CAMP-PKA pathway seems to play a key role in the early stages of hippocampal $\rightarrow$ PFC LTP (Gurden et al., 2000; Jay, 2003) and D1-NMDA interactions are PKA dependent, it is possible that their synergistic action on pyramidal cell excitability facilitates cortical plasticity mechanisms, reinforcing ongoing activity in the PFC. Thus, a D1 enhancement of NMDA responses in PFC pyramidal cell excitability may provide a cellular mechanism by which DA sustains prolonged depolarizations, acting as a state-dependent stabilizer of the appropriate neural ensembles (O’Donnell et al., 1999; O’Donnell 2003).

In contrast to D1 receptors, the D2 role in PFC function is less clear. There is evidence suggesting a D2 modulation of working memory (Druzin et al., 2000) and age-related PFC cognitive functions (Arnsten et al., 1995). The inhibitory D2 effects on pyramidal cell excitability may constitute important cellular mechanisms for selection of relevant information in the PFC. Both the direct (D2-AMPA) and indirect (D2-NMDA via GABA activation) interactions can result in dampening of excitatory inputs, which would contribute to fine tuning of PFC cell firing. Indeed, it has been shown that $\mathrm{GABA}_{\mathrm{A}}$ activation improves spatial selectivity of PFC pyramidal cell firing (Rao et al., 2000), suggesting that interactions between pyramidal and nonpyramidal neurons are important in shaping neuronal activity engaged in working memory processes.

During conditions eliciting DA cell burst firing (i.e., salient stimuli) (Schultz, 2002), the phasic DA increase in the PFC activates both $\mathrm{D} 1$ and $\mathrm{D} 2$ receptors. It is possible that the inhibitory D2 effect on AMPA-mediated responses may increase the signalto-noise ratio by attenuating weak signals, whereas the concurrent dampening of NMDA effects by D2 receptors via an enhanced GABA transmission may be a critical element in the control of timing and spatial selectivity of pyramidal cell firing (Rao et al., 2000). For instance, in vivo intracellular studies assessing responses of PFC neurons to ventral tegmental area stimula- tion have revealed a prolonged plateau depolarization along with suppression of action potential firing (Lewis and O'Donnell, 2000). This persistent depolarization was reduced by a D1 antagonist; thus, it could represent a D1 enhancement of NMDA function. The decrease in firing could be the result of both direct and indirect (via GABA interneurons) D2 actions. Such prolonged depolarization with reduced firing was proposed to reflect a gating mechanism of the appropriate PFC neural ensemble, although it reduced irrelevant information. Thus, combined activation of D1, D2, GABA, and glutamate receptors may allow a "gating with filtering" phenomenon by virtue of the interactions reported here. Disruption of these interactions in the PFC may contribute to abnormal coordination of pyramidal neuron firing and may yield the cognitive deficits observed in schizophrenia and related neuropsychiatric disorders (O'Donnell and Grace, 1998; Laruelle, 2000).

\section{References}

Arnsten AF, Cai JX, Steere JC, Goldman-Rakic PS (1995) Dopamine D2 receptor mechanisms contribute to age-related cognitive decline: the effects of quinpirole on memory and motor performance in monkeys. J Neurosci 15:3429-3439.

Baldwin AE, Sadeghian K, Kelley AE (2002) Appetitive instrumental learning requires coincident activation of NMDA and dopamine D1 receptors within the medial prefrontal cortex. J Neurosci 22:1063-1071.

Cepeda C, Levine MS (1998) Dopamine and N-methyl-D-aspartate receptor interactions in the neostriatum. Dev Neurosci 20:1-18.

Cepeda C, Radisavljevic Z, Peacock W, Levine MS, Buchwald NA (1992) Differential modulation by dopamine of responses evoked by excitatory amino acids in human cortex. Synapse 11:330-341.

Cepeda C, Buchwald NA, Levine MS (1993) Neuromodulatory actions of dopamine in the neostriatum are dependent upon the excitatory amino acid receptor subtypes activated. Proc Natl Acad Sci USA 90:9576-9580.

Cepeda C, Colwell CS, Itri JN, Chandler SH, Levine MS (1998) Dopaminergic modulation of NMDA-induced whole cell currents in neostriatal neurons in slices: contribution of calcium conductances. J Neurophysiol 79:82-94.

Dodt H-U, Frick A, Kampe K, Zieglgänsberger W (1998) NMDA and AMPA receptors on neocortical neurons are differentially distributed. Eur J Neurosci 10:3351-3357.

Druzin MY, Kurzina NP, Malinina EP, Kozlov AP (2000) The effects of local application of D2 selective dopaminergic drugs into the medial prefrontal cortex of rats in a delayed spatial choice task. Behav Brain Res 109:99-111.

Dunah AW, Standaert DG (2001) Dopamine D1 receptor-dependent trafficking of striatal NMDA glutamate receptors to the postsynaptic membrane. J Neurosci 21:5546-5558.

Floresco SB, Phillips AG (2001) Delay-dependent modulation of memory retrieval by infusion of a dopamine $\mathrm{D}_{1}$ agonist into the rat medial prefrontal cortex. Behav Neurosci 115:934-939.

Flores-Hernandez J, Cepeda C, Hernandez-Echeagaray E, Calvert CR, Jokel ES, Fienberg AA, Greengard P, Levine MS (2002) Dopamine enhancement of NMDA currents in dissociated medium-sized striatal neurons: role of D1 receptors and DARPP-32. J Neurophysiol 88:3010-3020.

Gao WJ, Krimer LS, Goldman-Rakic PS (2001) Presynaptic regulation of recurrent excitation by D1 receptors in prefrontal circuits. Proc Natl Acad Sci USA 98:295-300.

Gonzalez-Islas C, Hablitz JJ (2003) Dopamine enhances EPSCs in layer IIIII pyramidal neurons in rat prefrontal cortex. J Neurosci 23:867-875.

Grobin AC, Deutch AY (1998) Dopaminergic regulation of extracellular gamma-aminobutyric acid levels in the prefrontal cortex of the rat. J Pharmacol Exp Ther 285:350-357.

Gulledge AT, Jaffe DB (1998) Dopamine decreases the excitability of layer V pyramidal cells in the rat prefrontal cortex. J Neurosci 18:9139-9151.

Gulledge AT, Jaffe DB (2001) Multiple effects of dopamine on layer V pyramidal cell excitability in rat prefrontal cortex. J Neurophysiol 86:586-595.

Gurden H, Tassin JP, Jay TM (1999) Integrity of the mesocortical dopaminergic system is necessary for complete expression of in vivo hippocampal-prefrontal cortex long-term potentiation. Neuroscience 94: 1019-1027. 
Gurden H, Takita M, JayTM (2000) Essential role of D1 but not D2 receptors in the NMDA receptor-dependent long-term potentiation at hippocampalprefrontal cortex synapses in vivo. J Neurosci 20:RC106(1-5).

Hernandez-Lopez S, Bargas J, Surmeier DJ, Reyes A, Galarraga E (1997) D1 receptor activation enhances evoked discharge in neostriatal medium spiny neurons by modulating an L-type $\mathrm{Ca}^{2+}$ conductance. J Neurosci 17:3334-3342.

Hernandez-Lopez S, Tkatch T, Perez-Garci E, Galarraga E, Bargas J, Hamm $\mathrm{H}$, Surmeier DJ (2000) D2 dopamine receptors in striatal medium spiny neurons reduce $\mathrm{L}$-type $\mathrm{Ca}^{2+}$ currents and excitability via a novel PLC $\beta 1$ IP3-calcineurin-signaling cascade. J Neurosci 20:8987-8995.

Jay TM (2003) Dopamine: a potential substrate for synaptic plasticity and memory mechanisms. Prog Neurobiol 69:375-390.

Kotecha SA, Oak JN, Jackson MF, Perez Y, Orser BA, Van Tol HH, MacDonald JF (2002) A D2 class dopamine receptor transactivates a receptor tyrosine kinase to inhibit NMDA receptor transmission. Neuron 35:1111-1122.

Lachowicz JE, Sibley DR (1997) Molecular characteristics of mammalian dopamine receptors. Pharmacol Toxicol 81:105-113.

Laruelle M (2000) The role of endogenous sensitization in the pathophysiology of schizophrenia: implications from recent brain imaging studies. Brain Res Brain Res Rev 31:371-384.

Levine MS, Li Z, Cepeda C, Cromwell HC, Altemus KL (1996) Neuromodulatory actions of dopamine on synaptically-evoked neostriatal responses in slices. Synapse 24:65-78.

Lewis BL, O'Donnell P (2000) Ventral tegmental area afferents to the prefrontal cortex maintain membrane potential "up" states in pyramidal neurons via D1 dopamine receptors. Cereb Cortex 10:1168-1175.

Lindvall O, Bjorklund A, Moore RY, Stenevi U (1974) Mesencephalic dopamine neurons projecting to neocortex. Brain Res 81:325-331.

Ling DS, Benardo LS (1999) Restrictions on inhibitory circuits contribute to limited recruitment of fast inhibition in rat neocortical pyramidal cells. J Neurophysiol 82:1793-1807.

Miller EK (2000) The prefrontal cortex and cognitive control. Nat Rev Neurosci 1:59-65.

Nicola SM, Surmeier J, Malenka RC (2000) Dopaminergic modulation of neuronal excitability in the striatum and nucleus accumbens. Annu Rev Neurosci 23:185-215.
O’Donnell P (2003) Dopamine gating of forebrain neural ensembles. Eur J Neurosci 17:429-435.

O’Donnell P, Grace AA (1994) Tonic D2-mediated attenuation of cortical excitation in nucleus accumbens neurons recorded in vitro. Brain Res 634:105-112.

O’Donnell P, Grace AA (1998) Dysfunctions in multiple interrelated systems as the neurobiological bases of schizophrenic symptom clusters. Schizophr Bull 24:267-283.

O’Donnell P, Greene J, Pabello N, Lewis BL, Grace AA (1999) Modulation of cell firing in the nucleus accumbens. Ann NY Acad Sci 877:157-175.

Petit TL, LeBoutillier JC, Gregorio A, Libstug H (1988) The pattern of dendritic development in the cerebral cortex of the rat. Brain Res 469:209-219.

Rao SG, Williams GV, Goldman-Rakic PS (2000) Destruction and creation of spatial tuning by disinhibition: $\mathrm{GABA}(\mathrm{A})$ blockade of prefrontal cortical neurons engaged by working memory. J Neurosci 20:485-494.

Salin PA, Prince DA (1996a) Spontaneous GABAA receptor-mediated inhibitory currents in adult rat somatosensory cortex. J Neurophysiol 75:1573-1588.

Salin PA, Prince DA (1996b) Electrophysiological mapping of GABAA receptor-mediated inhibition in adult rat somatosensory cortex. J Neurophysiol 75:1589-1600.

Schultz W (2002) Getting formal with dopamine and reward. Neuron 36:241-263.

Snyder GL, Fienberg AA, Huganir RL, Greengard P (1998) A dopamine/D1 receptor/protein kinase A/dopamine- and cAMP-regulated phosphoprotein $\left(M_{\mathrm{r}} 32 \mathrm{kDa}\right) /$ protein phosphatase-1 pathway regulates dephosphorylation of the NMDA receptor. J Neurosci 18:10297-10303.

Sternweis PC, Smrcka AV (1992) Regulation of phospholipase C by G proteins. Trends Biochem Sci 17:502-506.

Surmeier DJ, Bargas J, Hemmings HC, Nairn AC, Greengard P (1995) Modulation of calcium currents by a D1 dopaminergic protein kinase/phosphatase cascade in rat neostriatal neurons. Neuron 14:385-397.

Wang J, O'Donnell P (2001) D1 dopamine receptors potentiate NMDAmediated excitability increase in layer $\mathrm{V}$ prefrontal cortical pyramidal neurons. Cereb Cortex 11:452-462.

Zhu JJ (2000) Maturation of layer 5 neocortical pyramidal neurons: amplifying salient layer 1 and layer 4 inputs by $\mathrm{Ca}^{2+}$ action potentials in adult rat tuft dendrites. J Physiol (Lond) 526:571-587. 